\title{
Išmaniosios gynybos koncepcijos pasekmès mažosioms Aljanso valstybėms
}

Prieš keletą metų NATO paskelbė išmaniosios gynybos (smart defence) iniciatyvą, kurios tikslas - išmaniai naudojant turimus resursus, net ir finansinès krizès sąlygomis, išlaikyti turimą karini potencialią. Šios straipsnio tikslas - išnagrinèti kaip mažosios NATO valstybès prièmè išmaniosios gynybos keliamus reikalavimus, kokios priežastys lėmė jų dalyvavimą konkrečiose išmaniosios gynybos iniciatyvose. Straipsnyje nagrinejjama, kaip valstybių dydis, geografija, politika ir kiti veiksniai lemia skirtingus valstybių veiksmus bendradarbiaujant su partneriais, nustatant pajègumų prioritetus ir pasirenkant specializacijos kryptis.

\section{Ivadas}

Išmaniosios gynybos koncepcija tampa vis svarbesnè NATO darbotvarkèje. Politikai, akademinè visuomenè gana greitai priprato prie prieš kelerius metus NATO generalinio sekretoriaus Anderso Fogho Rasmusseno įvesto išmaniosios gynybos termino, kuris dabar sutinkamas ne tik NATO biurokratu žodyne, bet ir populiariojoje literatūroje.

Išmanioji gynyba NATO žodyne, kaip ir pajègų sutelkimo ir pasidalinimo (pooling and sharing) Europos Sąungoje ${ }^{1}$, atsirado ekonominès krizès metu. Mažejant gynybos biudžetams, NATO ir ES šalių politikai turèjo surasti atsakymą, kaip galima patenkinti vis didejjančius karinių operacijų reikalavimus. Išmaniosios gynybos koncepcijoje turèjo būti pasiūlyti būdai, kaip dalinantis pajègumais, peržiūrint prioritetus, geriau koordinuojant veiksmus galima pasiekti geresnių rezultatų negu veikiant kiekvienai valstybei atskirai ${ }^{2}$. Pagrindiniu išmaniosios gynybos šǔkiu tapo skambi frazè „padaryti daugiau

\footnotetext{
* Dr. Vaidotas Urbelis - Lietuvos karo akademijos Politikos mokslų katedros dèstytojas. Adresas korespondencijai: Šilo 5a, 10332 Vilnius; tel. (8 5)210 3569; el. p. vaidurb@gmail.com.

${ }^{1}$ Plačiau apie NATO ir Europos Sajungos iniciatyvų santykį: Giovanni Faleg and Alessandro Giovannini "The EU between Pooling \& Sharing and Smart Defence Making a virtue of necessity?", Centre for European Policy Studies, 2012.

${ }^{2}$ Išmanioji gynyba (smart defence), NATO, http://www.nato.int/cps/en/SID-F429D52E-AB1A4085/ natolive/topics_84268.htm?
} 
turint mažiau“" (to do more with less). NATO pabrèžia, siekdamos igyvendinti išmaniosios gynybos tikslus, valstybès privalo:

- teikti pirmenybę labiausiai NATO (o ne atskirai valstybei) reikalingu pajègumų plètojimui,

- specializuotis tose srityse, kur jos turi didžiausią patirtį,

- ieškoti daugianacionalinių sprendimų ir bandyti kartu spręsti iškylančias problemas.

Politiškai visos NATO valstybės parèmė šią idèją. Išmanioji gynyba minima daugelyje ministrų komunikatų ir Čikagos viršūnių susitikimo deklaracijoje. Tačiau neoficialiai yra nemažai skeptiškų balsų, abejojančiu išmaniosios gynybos reikšme. Skeptikai pabrěžia, kad dažniausiai pateikiami išmaniosios gynybos atvejai (strateginių pervežimų iniciatyva, oro policija Baltijos šalyse, priešraketinè gynyba) buvo pradèti gerokai anksčiau, nei NATO generalinis sekretorius sugalvojo išmaniosios gynybos terminą. Jie pabrēžia, kad išmanioji gynyba - tai daugiausia senų iniciatyvų „ipakavimas“, suteikiant joms naują pavadinimą, bet nekeičiant esmès. Politikai prašo parodyti konkrečių veiksmų rezultatus, kur išmanioji gynyba sutaupe pinigų ar sukūrè papildomus pajègumus. Kol tokių pavyzdžių nebus, skeptikai ir toliau kvestionuos išmaniosios gynybos privalumus.

Nepaisant kritikos, dauguma mažųjų NATO valstybių labai rimtai nusiteikusios igyvendinti pagrindinius išmaniosios gynybos nuostatus. Mažosios valstybès labiausiai suinteresuotos išmaniosios gynybos sèkme. Jų saugumas daugiau negu didžiụjų valstybių yra priklausomas nuo kolektyvinių gynybos garantijų tvirtumo. Išmaniosios gynybos sẻkmè sustiprintų NATO pajegumus ir prisidètų prie jų saugumo užtikrinimo. Nesèkmès atveju, iškiltų grèsmė Aljanso vienybei, taip pat ir mažųjų valstybių saugumui. Iš kitos pusès, joms išmaniosios gynybos igyvendinimas kelia nemažai iššūkių. Jos turi atsižvelgti ị savo suvereniteto apribojimus, priklausomybę nuo didžiųjų šalių ir ieškoti naštos su savo sajungininkais pasidalinimo būdų. İ šiuos iššūkius nèra lengva atsakyti.

Šio straipsnio tikslas yra įvertinti išmaniosios gynybos koncepciją iš mažosios valstybès perspektyvos. Šis straipsnis bandys sujungti teorini išmaniosios gynybos modeli su realybe, t. y. kaip praktiškai mažosios valstybès bando atsakyti i i išmaniosios gynybos keliamus iššǔkius. Straipsnis padalintas i dvi dalis. Pirmojoje bus nagrinëjami veiksniai, kurie nulemia vienokị ar kitokị mažųjų valstybių elgesị. Antrojoje, bus apžvelgiami konkretūs mažųjų valstybių veiksmai ir praktinés iniciatyvos, kurias jos ryžtasi ịgyvendinti išmaniosios gynybos rèmuose. 
Šiame straipsnyje kiekviena valstybė, kurios gynybos biudžetas yra mažesnis kaip 10 mlrd. JAV dolerių, bus priskirta mažųjų valstybių kategorijai. Tai apima visas NATO valstybes, išskyrus JAV, Jungtinę Karalystę, Prancūziją, Vokietiją, Italiją, Kanadą, Turkiją, Ispaniją ir Nyderlandus. Šis sąrašas beveik identiškas su R. de Wijko paskelbta studija, kurioje vertinamas NATO šalių karinis pajègumas. R. de Wijkas aiškiai pabrèžia, kad mažųjų valstybių išskirtinis bruožas - nesugebejjimas turèti pilno karinių pajègumų spektro ir negalejjimas savarankiškai panaudoti karinių instrumentų kitose pasaulio vietose. Mažųjų valstybių veikimo laisvè yra smarkiai apribota didžiujų valstybių, o jų saugumo garantas yra kolektyvinès gynybos susitarimai.

Nors dauguma NATO šalių yra mažosios valstybès, tačiau akademinèje literatūroje retai analizuojamos joms iškylančios išmaniosios gynybos problemos. Tiesa, dar prieš išmaniosios gynybos termino atsiradimą, nemažai mažujų valstybių galimų veiksmų buvo aptarta M. Flournoy ir J. Smith studijoje „European Defence Integration: Bridging the Gap between Strategy and Capabilities“. Nors joje nèra atskirtų skyrių, skirtų mažosioms valstybèms, tačiau pateikiama daugybẻ pavyzdžių ir teorinių apibendrinimų bandant paaiškinti jų elgesị. A.Grimes ir J.Rolfe savo studijoje „Optimal Defence for a Small Country“ konceptualiai aptaria Naujajai Zelandijai kylančias problemas bendradarbiaujant su savo didesniąja kaimyne. L. Struwe`as, M. Rasmussenas ir K. Larsenas 2012 m. paskelbtoje studijoje „To Be, or Not to Be“ (Smart Defence, Sovereignty and Danish Defence Policy) aptaria Danijai kylančius išmaniosios gynybos iššūkius.

Keletas svarbių lyginamụjų darbų buvo labai naudingi rašant ši straipsnị tai R. de Wijko studija „Security Implications of NATO Transformation for Smaller Members“ ir R. Beeweso, M. Bogerso straipsnis „Ranking the Performance of European Armed Forces“. Šiuose straipsniuose bandoma statistiškai palyginti mažųjų ir didžiụjų valstybių karinius pajègumus. Tai leidžia daryti išvadas apie išmaniosios gynybos privalumus ir trūkumus.

\section{Išmaniosios gynybos keliami iššūkiai kolektyvinès gynybos organizacijoje}

Kiekvienos šalies gynybos politika apibrèžia karinès jègos naudojimo priemones ir būdus. Karinè jèga naudojama pasiekti jų užsienio ir saugumo politikos tikslams. Šalių kariuomenių pagrindinis uždavinys yra ginti šalies nepriklausomybę, garantuoti jos laisvę ir saugumą. Siekdami šių tikslų, karo strategai ir planuotojai, turi surasti būdus kaip efektyviausiai panaudoti karinę 
galią neišeinant už turimų išteklių ribų. Išmanioji gynyba jiems yra svarbiausia būtent todèl, kad siekia išlaikyti ir netgi plèsti karines pajègas nedidinant gynybos biudžetų.

Reikia pažymėti, kad išmanioji gynyba nèra pirmasis bandymas rasti efektyvesnių pinigų naudojimo būdų. Šalys jau daug metų savarankiškai arba su partneriais ieško inovatyvių sprendimų. Tačiau priešingai nei kitos iniciatyvos, išmaniosios gynybos iniciatyva bando konceptualizuoti visus ligšiolinius bandymus ir sukuria struktūrą, kurią naudodamos valstybès gali bendradarbiauti ieškodamos naujų sprendimų, kaip taupyti turimus išteklius. NATO sukūrẻ netgi vadybos struktūrą, kuri turi prižiūrèti išmaniosios gynybos idẻjų igyvendinimą. NATO šalys pavede NATO generalinio sekretoriaus pavaduotojui ir Aljanso transformacijos vadavietes vadui (Commander of the Alliance Command Transformation) prižiūrèti ši procesą.

Nors išmaniosios gynybos idëjos yra universalios, nuo pat pradžiu NATO šalių požiūris ị išmaniosios gynybos iniciatyvą nebuvo vienodas. Šalių grėsmių supratimas, strateginè kultūra ir turimi ištekliai nulemia, kad jų politika tam tikrų NATO iniciatyvų atžvilgiu gerokai skiriasi. Kai kurios iš jų jau daugelį šimtmečių vykdo ekspedicines operacijas, kitos - koncentruojasi į teritorinę gynybą. Gynybos išlaidos svyruoja nuo 0,7 iki 4 procentų nuo BVP. Kai kurios šalys nusprendžia išlaikyti visą pajėgumų spektrą, kitos nusprendžią kai kurių (pavyzdžiui, povandeninių laivų ar tankų) atsisakyti. Užtenka palyginti Graikiją ir Čekiją - nors jos abi panašaus dydžio, panašios gyventojų skaičiumi ir ekonomika valstybès, tačiau jų strateginè kultūra ir tarptautiniai ịsipareigojimai gerokai skiriasi.

Narystė NATO yra papildomas svarbus veiksnys, kuris lemia, kaip valstybės apibrěžia karinès jègos vietą savo valstybės strategijoje. Aljansas pajėgus veikti tik tada, kai valstybès kuria pajėgas, galinčias ateiti ị pagalbą ir užtikrinti viena kitos gynybą. Tokios pajègos turi būti perdislokuojamos ir išlaikomos ne tik savo, bet ir kitų valstybių teritorijoje. Priklausomybė nuo kitų šalių gebejjimo ginti viena kitos interesus ir teritoriją yra didžiulis Aljanso narius vienijantis veiksnys. Nors tapdamos NATO narėmis šalys neatsisako savo suverenumo, tačiau narystė Aljanse smarkiai apriboja jų veiksmų laisvę sprendžiant dẻl karinių pajègumų plėtros. Kaip pažymèjo Struwe'as, Rasmussenas ir Larsonas „NATO sutarties 5 straipsnis reiškia, kad valstybès suverenitetas nebèra tik jos vienos reikalas. Esant dideliam tarpusavio integracijos laipsniui, galioja domino efektas, t. y. viena valstybė vis labiau įtraukiama ị kitos reikalus, ịskaitant karo atvejus"'

\footnotetext{
${ }^{3}$ L.Struwe, M.Rasmussen, K.Larsen "To Be, or Not to Be (Smart Defence, Sovereignty and Danish Defence Policy), 2012, p. 22.
} 
NATO turi realių įrankių, kaip individualias šalių pastangas palenkti bendram kolektyvinès gynybos labui. Visos NATO šalys yra NATO gynybos planavimo proceso, kurio metu Aljanso transformacijos vadaviete nustato kiekvienai šaliai siektinus pajegumus, reikalingus įvykdyti NATO ambicijų lygi, dalyvès. Šio proceso metu ir po ilgų konsultacijų su šalimis NATO gynybos planuotojai kiekvienai valstybei pateikia pajègumų siekių sąrašą, t. y. pajègumų paketą, kurị šalis turi igyvendinti per tam tikrą laikotarpị. Pateikdama pajėgumų siekius NATO tiesiogiai daro ịtaką valstybių karinio planavimo prioritetams ir plètros planams. Jų ịtaka ypač pastebima mažų šalių atveju, nes būtent joms pajègumų siekių ịgyvendinimas reiškia didžiausius iššūkius.

Teoriškai pajègumų siekiai galètų būti ịgyvendinami tradiciniu būdu, t. y. kiekviena šalis kurdama savo karines pajègas, tam tikrus vienetus priskirtų bendrosioms NATO reikmèms. Aljansas šiuo atveju tik apibrèžtų suderinamumo reikalavimus, bendrus standartus ir procedūras, tačiau visi pajègumo sukūrimo rūpesčiai liktų pačių valstybių reikalas. Išmaniosios gynybos koncepcija siekia iš pagrindų peržiūrèti šią tradicinę ir per dešimtmečius nusistovejjusią tvarką. Visi trys išmaniosios gynybos elementai - prioritetizacija, specializacija ir daugianacionališkumas - siūlo valstybėms nuo pat pradžių žiūrèti ị bet kokio pajègumo kūrimą kitaip - pirma ịvertinti, ar šis pajègumas reikalingas bendriesiems Aljanso poreikiams, antra, išnagrinèti, ar to pajègumo geriau nesukurtų kiti sąjungininkai, trečia, ar nevertètų jo kurti kartu su kitais. Tokiu būdu, valstybès nuo pat pradžių turi ịvertinti karinių pajègumų plètrą daug plačiau nei to reikalauja nacionaliniai poreikiai. Toks požiūris leidžia taupyti resursus, tačiau priklausomybè nuo kitų gali ryškiai sumažinti valstybès autonomiją.

Ne visos valstybès vienodai jautriai reaguoja ị ši iššūkị. Pavyzdžiui, priklausomybè nuo kitos šalies strateginio pervežimo pajègumų gali būti labai jautrus klausimas šaliai, kuri nori savarankiškai veikti tolimuose pasaulio kampuose, tačiau mažai relevantiška mažai valstybei, kurios prioritetas yra teritorinė gynyba. Kai kurioms šalims nepriklausomos branduolinès programos išlaikymas yra svarbus suvereniteto klausimas, kitoms tai mažai įdomus klausimas. Todèl kituose straipsnio skyriuose bus siekiama pateikti paaiškinimus, kodèl valstybių reakcijos būna tokios skirtingos.

\subsection{Suverenitetas ir užtikrintas prieinamumas}

Viena iš išmaniosios gynybos pasekmių yra mažų valstybių priklausomybè nuo kitų šalių pajègumų. Idealiu atveju tai turètų vykti pagal iš anksto 
suplanuotos specializacijos (specialization "by design") formulę, kai valstybès susitaria investuoti $\mathfrak{i}$ tas sritis, kur jos jaučiasi stipriausiai ir koordinuoja finansinių investicijų pasiskirstymą tarp įvairių pajėgumų. Taip pat galutinị sprendimą dèl karinès jègos naudojimo jos pasilieka sau, taip išlaikydamos savo suverenitetą. ${ }^{4}$ Tačiau, kai sprendimas yra priimtas ir valstybè atsisako tam tikrų pajégumų plètros dèl bendro gèrio, faktiškai ji tampa priklausoma nuo kitų šalių, kurios tuos pajègumus išlaiko.

Gynybos analitikai sutinka, kad išmaniosios gynybos kontekste, užtikrintas prieinamumus prie kitos šalies arba bendrai kuriamų pajegumų yra svarbiausias išmaniosios gynybos iššūkis. Galima išskirti keletą šios problemos pagrindinių kliūčių - karinès (pavyzdžiui, sąjungininkai nesugeba sukurti pajėgumo pagal numatytus standartus), politinès (pavyzdžiui, vienas iš sąungininkų dèl politinių priežasčių atsisako pateikti pajègumus operacijai) arba techninès (pavyzdžiui, bendras pajègumas jau naudojamas kitur).

Pirmasis iššūkis kyla, kai krizès metu to paties pajègumo prisireikia visiems ir vienu metu. Net ir idealiame pasaulyje nèra garantijos, kad kritinis pajègumas, dèl kurio esi priklausomas nuo kito sąungininko, bus prieinamas. Pavyzdžiui, didelès karinès operacijos atveju tikètina, kad visiems beveik vienu metu prireiks strateginio pervežimo pajėgumo. Specializacijos atveju šio pajègumo savininkas greičiausiai stengsis pirma patenkinti savo paties poreikius, $o$ tik paskui leis juo pasinaudoti sąungininkams. Daugianacionalinio pajėgumo atveju valstybès gali nesutarti, kuri pirma galès juo pasinaudoti.

Antras svarbus kliuvinys yra politiniai skirtumai. Nuolatinè veikla kartu ir bendri iššūkiai vienija sąjungininkus, tačiau skirtumai išlieka. Europos valstybès buvo susiskaldžiusios karo Irake metu, kai kurios anksti pasitrauke iš Afganistano, ne visos dalyvavo NATO operacijoje Libijoje. Pastaruoju atveju kai kurios nedalyvaujančios valstybės netgi atsisakè padèti dalyvaujančioms, kai joms baigèsi amunicija ${ }^{5}$. Nors tokia situacija mažai tikètina kolektyvinès gynybos atveju, bet tarptautinèse misijose tai neišvengiama - ne visada visos valstybės dalyvaus kiekvienoje tarptautinejje operacijoje. Kartais, politiniai skirtumai gali sutrukdyti netgi bendrų NATO pajegumų panaudojimą, kaip tai atsitiko NATO AWACS dislokavimo Afganistane atveju' ${ }^{6}$.

Autonomijos ir veiksmų laisvės suvaržymai dèl politinių priežasčių gali būti pakankamas pagrindas valstybèms atsisakyti tam tikrų išmaniosios gy-

\footnotetext{
${ }^{4}$ Išmanioji gynyba (Smart defence), NATO, http://www.nato.int/cps/en/natolive/topics_84268.htm ${ }^{5}$ J.Henius "Specialization - the Gordian Knot of NATO's Smart Defence" p. 29 iš J.Henius, J.L McDonald Smart Defence: A Critical Appraisal, NDC Forum Paper, Rome, 2012.

${ }^{6}$ Germany says has no plans to boost Afghan AWACS force, Reuters, 2011-01-09 http://www.reuters.com/article/2011/01/09/us-germany-afghanistan-awacs-idUSTRE70828U20110109
} 
nybos projektų. Mažosios valstybės yra ypatingai jautrios tokiems iššūkiams. Jos turi tik dalį reikiamų pajègumų spektro, todèl daugelyje sričių jos tampa priklausomos nuo kitu valstybių. Ši priklausomybè gali būti politinès ịtampos šaltiniu ir nepasitikèjimo didelèmis šalimis įkaite. Todèl mažosios valstybès visada sieks rasti balansą tarp dviejų poliu - specializacijos ir visų pajègumų spektro. Jeigu leidžia aplinkybès, jos gali bandyti rinktis - išlaikyti daugelio reikalingų pajègumų pagrindus, neatsisakydamos gyvybiškai svarbių funkcijų, arba prisiimti riziką ir eiti išlaidų požiūriu efektyviausiu keliu.

\subsection{Išmanioji gynyba ir gynybos išlaidos}

Išmanioji gynyba - tai atsakas i poreikị taupyti pinigus arba juos leisti protingiau. NATO generalinio sekretoriaus Rasmusseno nuomone, politikai iš karto suprato išmaniosios gynybos vaidmenį mažejjančių gynybos biudžetų ir finansinių krizių metais: „todèl, mes vadiname šią iniciatyvą išmaniosios gynybos iniciatyva, nes jinai leidžia išmaniau naudoti turimus pinigus gynybai “7

Šiuo požiūriu išmaniosios gynybos idejjos yra vienodai aktualios tiek mažoms, tiek didelėms Aljanso narems. Mažosios valstybès turètų dar kitų papildomų priežasčių dalyvauti išmaniosios gynybos projektuose. Dèl mažų gynybos išlaidų joms sunkiau pasiekti masto ekonomijos efektą, todèl autonomijos išlaikymas joms kainuoja brangiau nei didesnèms valstybèms. JAV gali sau leisti išlaikyti Nacionalini gynybos universitetą, kur dirba 363 aukštos kvalifikacijos déstytojai, tačiau jei atsižvelgtume i proporcijas, kiek dėstytojų tenka vienam kariui, tai Lietuva galètų išlaikyti tik 2 dèstytojus Lietuvos karo akademijoje. Ta pati logika tinka tiek ịsigijimams, tiek mokymams, tiek operacijoms. Mažos valstybės neišvengiamai turès proporcingai didesnes administracines ir išlaikymo išlaidas palyginti su didesnèmis valstybėmis.

Problemos mastą didina dar ir tai, kad mažosios valstybès gynybai neišleidžia daugiau nei didžiosios palyginti pagal gynybos išlaidų procentą nuo BVP. Netgi atvirkščiai - pagal ši procentą daugiausiai išleidžia dvi didelès valstybès - JAV ir Jungtinè Karalystè, o gynybos išlaidų lentelès apačioje yra mažosios valstybès.

\footnotetext{
7 "NATO leaders to consider Smart Defence in Chicago", Strategic Comments, Vo.18, N.19, http://www. iiss.org/publications/strategic-comments/past-issues/volume-18-2012/may/nato-leaders-to-considersmart-defence-in-chicago/
} 


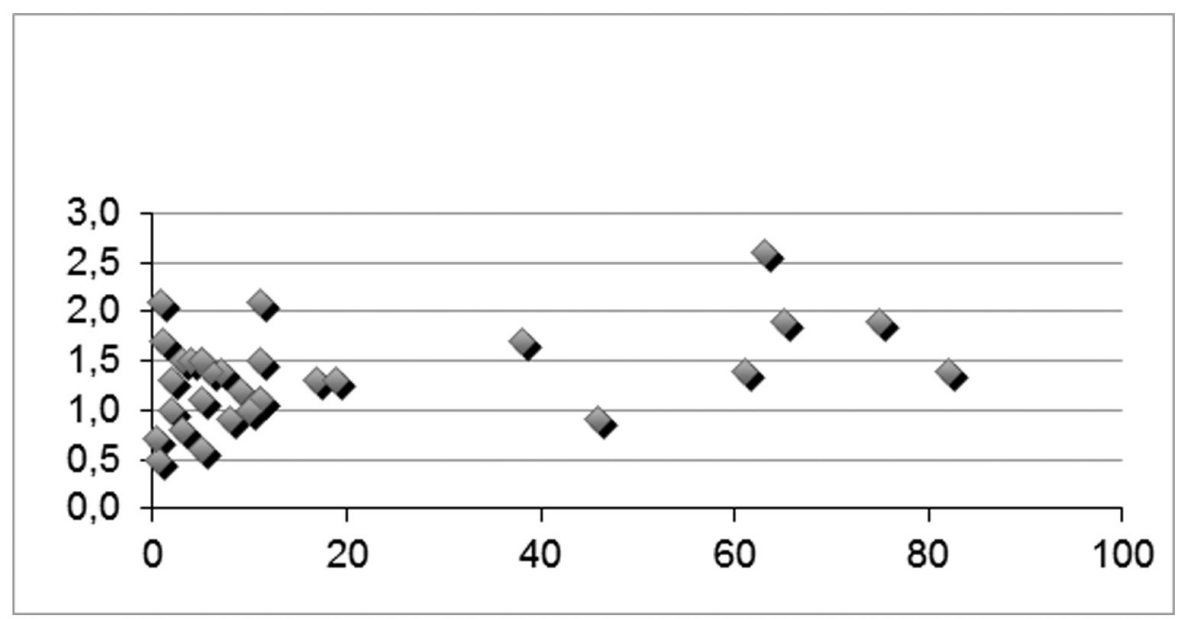

1 pav. Gynybos išlaidos: procentas nuo BVP ir gyventojų skaičiaus Nėra jokios koreliacijos tarp valstybės dydžio (pagal gyventojų skaičių) ir išlaidų gynybai procento nuo BVP NATO ir ES valstybèse.

Dèl mažų gynybos biudžetų ir didelių administracinių ir išlaikymo išlaidų, mažosios valstybès nèra pajegios sukurti plataus spektro karinių pajègų. Tai verčia jas priimti drastiškus sprendimus dèl specializacijos krypčių ar nišinių pajègumų plètros siekiant maksimaliai prisidèti prie kolektyvinès gynybos keliamų reikalavimų.

Grimesas ir Ralfeas savo straipsnyje „Optimal Defence Structure for a Small Country“ pasiūle teorinị modelį, kaip valstybès priima sprendimus dèl nišinių pajègumų plètros arba jų atsisakymo. Jie priëjo prie išvados, kad jeigu maža ir didelè valstybė turi panašius tikslus ir pasitiki viena kita „maža valstybė maksimaliai prisidès prie abiejų šalių bendros gynybos, jei pasiryš plètoti mažą labai gerai parengtų pajegumų spektrą. Kuo didesnè šalis, tuo didesni pajègumų spektrą ji galètų išlaikyti”" .

Jų studija daro išvadą, kad prioritetizavimas, specializacija ir daugianacionalinès iniciatyvos aljansuose yra efektyviausias kelias siekiant maksimalios naudos. Ši logika yra ypač svarbi NATO, kur valstybès yra susietos 5 straipsnio garantijomis, o jų nacionaliniai plètros planai yra lemiami NATO gynybos planavimo. Kaip teigia Struwe'as, Rasmussenas ir Larsenas, gynybos ịranga nuolat brangsta, todèl logiška, kad valstybès siekia masto ekonomijos darydamos pirkimus. Tačiau šių bendrų veiksmų išankstinè sąlyga yra didelis šalių suderina-

\footnotetext{
${ }^{8}$ A.Grimes, J.Rolfe "Optimal Defence Structure for a Small country", Defence and Peace Economics, 2002, Vol.12(4), p. 275.
} 
mumo laipsnis. ${ }^{9}$ Bendras NATO gynybos planavimas skirtas sukurti bendrus standartus ir tikslus, kuriais remdamosi šalys galètų igyvendinti išmaniosios gynybos projektus.

Išmaniosios gynybos koncepcija politiškai ịprasmina šias efektyvumo ir subalansuotos plètros pastangas tuo metu, kai daugumoje NATO šalių gynybos biudžetai ir toliau mažèja. Tuo tikslu NATO planuotojai turi bandyti eliminuoti nacionalines baimes, politinius nesusipratimus ir kitas kliūtis, trukdančias pasiekti išmaniosios gynybos iškeltus tikslus.

\subsection{Mažosios valstybẻs tarptautinėse operacijose}

Gynybos išlaidos nèra vienintelis veiksnys, lemiantis, kaip valstybès atsako i išmaniosios gynybos iniciatyvą. Šiame dešimtmetyje tarptautinès operacijos dominuoja NATO darbotvarkeje. Posakis „nesakyk man, kiek turi karių namie, bet pasakyk, kiek gali jų išlaikyti operacijose“ parodo ị operacinius pajėgumus nukreipto mąstymo logiką. NATO siekia, kad valstybès turètų mažiausiai 50 procentų perdislokuojamų ir 10 procentų išlaikomų sausumos pajègų. Šis reikalavimas smarkiai atsiliepia mažujų šalių gynybos planavimui ir atsakui $\mathfrak{i}$ išmaniosios gynybos iniciatyvas.

Galimybè sukurti perdislokuojamas pajègas nèra tiesiogiai susijęs su valstybės dydžiu. Beeres ir Bogers atliktoje empirineje studijoje nustaté, kad kai kurios šalys, skiriančios aukštą procentą nuo BVP gynybai, nebūtinai gerai pasirodo išlaikomų operacijose pajègų statistikoje. Taip pat šalys, išleidžiančios mažai pinigų gynybai, kartais išlaiko sąlyginai dideles kontribucijas operacijose. $^{10}$

NATO šalių dalyvavimas NATO vadovaujamoje Tarptautinès saugumo pagalbos pajegose (ISAF) Afganistane yra geriausias Beeres ir Bogers patvirtinimas. Kadangi ISAF yra svarbiausia NATO operacija, natūralu, kad daugumos valstybių didžiausia kontribucija yra būtent šioje operacijoje, jai skiriami ir didžiausi resursai.

Lentelè Nr. 1 parodo, kad santykinai mažosios Europos valstybės yra aktyvesnès ISAF operacijoje už didžiąsias. Tačiau šis skirtumas yra nedidelis ir jeigu pridètume JAV kontribuciją, tai mažųjų valstybių pranašumas ištirptų (150 mln. mažųjų šalių gyventojų išlaiko 9 tūkstančius karių Afganistane, 758 mln. didžiưjų valstybių gyventojų - 116 tūkstančių). Didžiosios valstybės taip

\footnotetext{
${ }^{9}$ L.Struwe, M.Rasmussen, K.Larsen op.cit., p. 25.

${ }^{10}$ R. Beeres, M. Bogers "Ranking the Performance of European Armed Forces", 2011, Defence and Peace Economics, Vol.23(1), p. 14.
} 
pat santykinai patyrė daugiau aukų. Nors kelių mažųjų Europos valstybių nuotolis buvo gana didelis, tačiau skaičiuojant nuo ISAF pradžios didžiųjų valstybių gyventojai prarado 3,7 kario vienam milijonui gyventojų, o mažosios tik 1 karị milijonui gyventojų.

Iš kitos pusės, mažosioms valstybėms yra du kartus sunkiau finansiškai išlaikyti savo karius ISAF operacijoje. Iš savo $47 \mathrm{mlrd}$. JAV dolerių biudžeto jos išlaiko 9 tūkstančius karių, o didžiosios išlaiko 116 tūkstančių karių iš 991 mlrd. JAV dolerių biudžeto.

1 lentelè. Mažosios ir didžiosios valstybès ISAF operacijoje

\begin{tabular}{|l|c|c|c|}
\hline & $\begin{array}{c}\text { Kariụ skaičius } \\
\text { ISAF/gynybos } \\
\text { biudžetas (mIn. JAV } \\
\text { dolerių) }\end{array}$ & $\begin{array}{c}\text { Karių skaičius ISAFI } \\
\text { gyventojų skaičius } \\
\text { (mln.) }\end{array}$ & $\begin{array}{c}\text { Aukos } \\
\text { (gyventojų skaičius } \\
\text { mln.) }\end{array}$ \\
\hline Mažosios valstybejs & 0.19 & 61.71 & 0.92 \\
\hline Didžiosios, išskyrus JAV & 0.10 & 58.07 & 1.91 \\
\hline Didžiosios j̨skaitant JAV & 0.12 & 152.75 & 3.68 \\
\hline
\end{tabular}

Mažosios valstybès dèl politinių priežasčių ir ateityje liks aktyvios tarptautinių operacijų dalyvės. Nepaisant mažų kariuomenių ir ekonominių veiksnių, jos išlieka pajegios išlaikyti ilgą laiko tarpą (ISAF atveju - daugiau kaip dešimt metų) gana nemažas kontribucijas tolimoje šalyje. Šis aktyvumas yra papildomas veiksnys, verčiantis mažas valstybes ieškoti naujų ir inovatyvių sprendimų, kaip nusiųsti ir išlaikyti pajègas ị brangiai kainuojančias tarptautines operacijas toli nuo gimtųjų namų.

\section{Mažujų šalių atsakas ị išmaniosios gynybos iniciatyvas}

Visos NATO valstybès teigiamai prièmè ir paremė NATO generalinio sekretoriaus iniciatyvą inovatyviai panaudoti turimus resursus siekiant sukurti gerai parengtas ir sąveikias karines pajègas. Politine parama atsispindejo konkrečiose bendradarbiavimo iniciatyvose ir projektuose, vykdomuose dvišaliu, daugiašaliu pagrindu, arba platesniuose NATO ir ES rẻmuose.

Praeitame skyriuje jau buvo pabrež̌ta, kad dèl ribotų resursų mažosios valstybès yra ekonomiškai labiau suinteresuotos dalyvauti išmaniosios gynybos projektuose nei didžiosios NATO narès. Mažųjų valstybių gynybos 
biudžetai yra menkesni, joms sunkiau pasiekti masto ekonomiją, jos santykinai išleidžia daugiau pinigu administracijai ir operacijoms. Todèl tikètina, kad mažosios šalys dažniau dalyvaus išmaniosios gynybos projektuose nei didžiosios.

Mažųjų valstybių dalyvavimas išmaniosios gynybos projektuose nèra be išlygų. Dalyvaudamos išmaniosios gynybos projektuose mažosios valstybès rizikuoja tapti priklausomos nuo savo sąjungininkų politikos, jų interesai ne visada sutampa su kitų sąjungininkų interesais. Mažosios valstybès yra ypač jautrios nacionalinio suvereniteto klausimu, ypač, jei santykiai su pagrindinèmis bendradarbiavimo partnerèmis kitose srityje (ekonomika, mažumų politika ir t. t.) nesiklosto puikiai.

Negalima išvesti bendros formulès, kuri apibrèžtų, kaip mažos valstybės apsisprendžia dèl dalyvavimo vienuose ar kituose išmaniosios gynybos projektuose. Jų apsisprendimas yra nenulemtas ne tik ekonominių veiksnių, bet ir politinès aplinkos, grèsmių sampratos ir savo vaidmens pasaulyje supratimo. Valstybès pačios nusprendžia, kokius pajègumus jos plètoja kolektyvinès gynybos reikmėms ir kaip tenkina nacionalinius poreikius. Kai kurios iš ju pasirenka „negatyvią specializaciją“, t. y. nusprendžia nepletoti tam tikros pajègumo rūšies. Kai kurios pasirenka investuoti i nišinius pajėgumus (pavyzdžiui, Čekijos pasirinkimas yra CBRB sritis ir sraigtasparnių pilotų rengimas). Kai kurios šalys didelį dèmesị skiria regioniniam bendradarbiavimui, kitos veikia savarankiškai. Kituose straipsnio skyriuose išsamiau bus aptarta valstybių nacionaliniai sprendimai ir jų logika.

\subsection{Funkcinis požiūris}

Nacionalinès kariuomenès susideda iš ịvairių pajėgų rūšių. Pagal jų užduotis kovos lauke jos dažniausiai skirstomos ị kovinius vienetus, kovinès paramos (angl. combat service) ir užnugario paramos arba logistikos (angl. combat service support) vienetus. Koviniai vienetai yra labiausiai matomi viešojoje erdvejje, tačiau be kitų vienetų teikiamos paramos (pavyzdžiui, degalų ar amunicijos tiekimo, technikos remonto, medicinos ir kitu pajègumų), koviniai vienetai nesugebètų išsilaikyti mūšio lauke. Papildomai kiekvienos šalies kariuomenè išlaiko nemažus mokymo vienetus, kurių užduotis apmokyti karius vykdyti jiems paskirtus uždavinius. Štabai ir administracinès struktūros privalo užtikrinti kasdieninị karinių vienetų funkcionavimą. Jiems išlaikyti taip pat reikalingos nemažos léšos, todèl kariuomenès visada stengiasi surasti balansą, kad vienos karinès funkcijos neužgožtų kitų. Pavyzdžiui, Ira- 
ko karo metu JAV kariuomeneje santykis tarp kovinių ir nekovinių vienetų buvo 1 prie 2,5, t. y. 40 procentų sudare koviniai ir kovinès paramos daliniai, 36 procentai - logistika, 24 procentai - štabai ir administracija. Jeigu iskaičiuotume kontraktininkus (t. y. ne kariuomenès personalas, bet civiliai asmenys, pasamdyti paremti karines operacijas), tai koviniai ir kovinès paramos dalinių dalis sumažetų iki 28 procentų. Tai puikiai atspindi modernią XXI amžiaus tendenciją, kai tik trečdalis karių tarnauja operaciniuose vienetuose ${ }^{11}$.

Išmaniosios gynybos koncepcija liečia visas kariuomenès funkcines sritis, nors konkretūs projektai ne visur yra lengvai igyvendinami.

Iš politinès pusès labiausiai matomas, nors kartu ir pats sunkiausias uždavinys yra bendrų koviniu ir kovinés paramos vienetų sukūrimas. Siekdamos sukurti bendrus vienetus, dalyvaujančios šalys turi labai viena kita pasitikèti, kitaip politiniai skirtumai gali sugriauti bendras pastangas. Net jeigu tokie projektai ir paskelbiami, dažniausiai jiems priskirtos nacionalinès pajègos prireikus gali būti išimamos iš bendro vieneto ir naudojamos nacionaliniams tikslams.

Korpuso lygmenyje egzistuoja nemažai bendrų vienetų, pavyzdžiui, Eurocorps, Šiaurès Rytų korpusas, ARRCC ir kiti. Jiems yra priskiriami divizijos ar brigados dydžio vienetai, o korpuso vadavietés ir kai kurie paramos elementai yra formuojami daugianacionaliniu pagrindu. Mažosios valstybès gali bendradarbiauti kurdamos ir mažesnius vienetus - bendras brigadas, batalionus ar specializuotus pajègumus. Tokio bendradarbiavimo pavyzdžiai - Pietryčiu Europos brigada (SEEBRIG), Baltijos batalionas (BALTBAT) ar kuriama Lietuvos-Lenkijos-Ukrainos brigada (LITPOLUKRBRIG).

Svarbiausias iššùkis kuriant bendrus kovinius ir kovinès paskirties vienetus - jų panaudojimas. Kadangi karinès jègos naudojimas ir dalyvavimas operacijose yra politinis sprendimas, dalyvaujančios šalys turi kartu šį sprendimą ir priimti. Jeigu nors viena šalis tam prieštarauja, tada kitos valstybès tampa šio sprendimo ịkaitèmis. Kuo daugiau valstybių dalyvauja bendro vieneto kūrime, tuo politinių problemų tikimybè dideja.

Patys didžiausi išmaniosios gynybos projektai vykdomi po bendru NATO arba ES skéčiu. Juos igyvendinant pasiekiamas masto ekonomijos efektas, tačiau projektų valdymas yra gana sudetingas. Mažoms valstybės didžiausias tokių projektų privalumas - dalyvaudamos didelèse programo-

\footnotetext{
${ }^{11}$ Išsamus tyrimas šia tema: J.McGrath "The Other End of the Spear: The Tooth - to-Tail Ratio (T3R) in Modern Military Operations", The Long War Series, Occasional Paper 23, Combat Studies Institute Press Fort Leavenworth, Kansas, 2007.
} 
se jos įsigyja pajėgumų, kurių neįsigytų tik savo jëgomis. NATO strateginio pervežimo iniciatyva, kai 11 valstybių kartu ịsigijo 3 strateginio transporto C17 lèktuvus, yra geras tokio bendradarbiavimo pavyzdys. NATO AGS programa vykdoma panašiu principu, nors, kaip ir strateginio pervežimo iniciatyvos atveju, teisinio statuso ir apmokejjimo klausimai ir politiniai nesutarimai lemia, kad projektas atsilieka nuo grafiko. Ateityje NATO priešraketinès gynybos sistema, nors daugiausia besiremianti nacionaliniais pajėgumais, bus puikus išmaniosios sistemos pavyzdys. Mažos valstybès galès prisidèti prie jos sukūrimo tiek pasiūlydamos savo nacionalinius pajègumus, tiek prisidèdamos prie bendros valdymo ir vadovavimo sistemos plètros.

Užnugario paramos ir logistikos vienetai ar funkcijos yra mažiau politiškai jautrios, šioje srityje integracija lengvesnè. Mažosioms valstybėms tai galimybè sujungti savo resursus ir juos ijungti ị didesnius vienetus. Bendros karo policijos kuopos, taktinio transporto vienetai, medicinos pajégumai ir t. t. gali tapti mažų valstybių nišiniais pajègumais, kuriems bendradarbiaudamos jos galètų skirti nemažą dèmesị.

Labai didelio dèmesio nusipelnè ekspedicinès logistikos pajègumai. Praktika, kai kiekviena valstybė sukuria savo operacijose dislokuotiems daliniams aprūpinti atskirą paramos logistinę sistemą, labai daug kainuoja, ypač toms valstybèms, kurių kontribucija nèra labai didelè. Kaip pastebèjo M. Flournoy and J. Smith, požiūris „atsivežk viską savo“ turi būti pakeistas sukuriant NATO daugianacionalinès logistikos vienetus, kurie svarbiausiomis paslaugomis (vandeniu, maistu, degalais, atsarginėm dalim ir t. t.) aprūpintų operacijose esančius vienetus ${ }^{12}$. Tokiu būdu būtų taupomi pinigai, supaprastinta aptarnavimo grandinė, atsirastų masto ekonomijos efektas. Kitas dažnai pateikiamas pavyzdys - Libijos operacijos metu Danijai greitai baigèsi naikintuvų amunicija. ${ }^{13}$ Jeigu NATO ar ES turètų bendras amunicijos atsargas, problema būtų greitai išspręsta ir Danija būtų galejusi naudotis bendrais resursais. Neatsitiktinai, po šios karčios patirties, Danija pasiūlè NATO pagalvoti apie bendrą projektą šioje srityje.

Mokymas ir parengimas yra bene svarbiausia sritis, kur egzistuoja didžiausias potencialas išmaniosios gynybos projektams. Ši sritis nèra politiškai jautri ir netgi projektų žlugimas neturètų ilgalaikių pasekmių. Bendri standartai, pratybos ir dalyvavimas operacijose suteikia papildomų paskatu valstybẻms ieškoti bendro sprendimo mokymo srityje.

\footnotetext{
${ }^{12}$ M. Flournoy, J.Smith, "European Defense Integration: Bridging the Gap between Strategy and Capabilities", Center for Strategic and International Studies (CSIS) Report, 2005, p.11.

${ }^{13}$ I.Daalder, "The Success of NATO Operations in Libya and the Vital Contributions of Partners Outside of NATO", US Department of State, http://fpc.state.gov/176760.htm
} 
Trijų Baltijos šalių ikurtas Baltijos gynybos koledžas yra vienas geriausiai matomų tokio bendradarbiavimo pavyzdžių. Jo tikslas - kartu ruošti aukštesniųjų laipsnių karininkus taip skatinant šalių bendradarbiavimą ir taupant resursus. Šis projektas nèra politinis - net jeigu visiškai neitikètino scenarijaus atveju Baltijos šalys sutartų panaikinti koledžą, tokio veiksmo pasekmès būtų valdomos, o koledžo funkcijas galètų perimti nacionalinès karo akademijos. Toks sprendimas papildomai kainuotų, netektume daugianacionalinės aplinkos, tačiau tai nesumažintų šalies kariuomenès operacinių pajègumų.

Mažosioms valstybėms daugianacionaliniai projektai mokymo srityje yra ypač svarbūs. Didžiosios valstybės gali išlaikyti savarankiškus mokymo ir karių rengimo pajègumus, net jeigu jų biudžetai ir mažeja. Mažosioms valstybẻms, siekiant suteikti kariams aukšto lygio parengimą, tokie bendri projektai yra būtinybè. Todèl specializacija mokymo srityje, dalinimasis poligonais ir kita mokymo infrastruktūra, netgi nuotolinis mokymasis, tampa vis svarbesnè išmaniosios gynybos dalis.

NATO kompetencijos centrai - tai dar vienas specializacijos ir resursu koncentravimo pavyzdys. Kompetencijos centrus valstybès steigia tose srityse, kur jos turi ypatingą ekspertizę ir ilgalaikę patirtị ${ }^{14}$. Tai puiki proga mažoms valstybėms užimti tam tikrą nišą NATO bendruomenèje ir plètoti jų interesus atitinkančias alternatyvas. Mažosios valstybès yra aktyvios šioje srityje, jos ịkūrẻ Karybos šalto oro sąlygomis (Norvegija), Kibernetinès gynybos (Estija), Energetinio saugumo (Lietuva), Apsaugos nuo improvizuotų sprogstamųjų užtaisų (Slovakija), Žmogiškosios žvalgybos (Rumunija), Apsaugos nuo cheminio, biologinio, radiacinio ir branduolinio ginklo (Čekija), Medicinos (Vengrija), Jūrinių minų (Belgija) kompetencijos centrus.

Administracija ir štabų egzistavimas labai susijęs su nacionalinio suverenumo klausimais, todèl šioje srityje išmaniosios gynybos projektai sunkiai isivaizduojami. Kol egzistuoja nacionalinès valstybès, tol šalyse bus gynybos ministerijos ir vadovavimo institucijos. Bendrų vadaviečių kūrimas taip pat politiškai jautrus klausimas, vienintelis tokio susitarimo pavyzdys yra bendras Belgijos ir Nyderlandų jūrų pajègų štabas. Bet ir ši vadavietė sukurta tokiu principu, kad reikalui esant abi valstybės galètų savarankiškai vykdyti nacionalines karines operacijas be kitos valstybès žinios.

${ }^{14}$ NATO, Centres of Excellence, http://www.nato.int/cps/en/natolive/topics_68372.htm 


\subsection{Esminių pajègumų išlaikymas}

Griežtai igyvendinus išmaniosios gynybos principus, NATO gynybos planavimo proceso rezultatas - NATO planuotojų galimas prašymas valstybių nebeplètoti pajègumų, kurie nèra reikalingi bendrosioms Aljanso reikmėms, nors yra svarbūs pačiai valstybei. Susidūrę su tokiu spaudimu, valstybių gynybos planuotojai bando rasti balansą tarp Aljanso poreikių tenkinimo ir poreikio išlaikyti pajégumą veikti atskirai ir vykdyti nepriklausomas karines operacijas. Galima būtų išskirti dvi atskiras sritis, kur valstybès nori išlaikyti savarankiško veikimo galimybę.

Pirma, valstybès gali pasirinkti išlaikyti esminius savigynos pajègumus. Šiuo atveju kai kurios šalys, net ir priklausydamos Aljansui, dèl vienų ar kitų priežasčiu (jos gali būti politinès, karinès ar kitokios) nusprendžia, kad jos turi sugebèti gintis savarankiškai, be sąjungininkų pagalbos.

Jų atsakas ị išmaniosios gynybos keliamus iššǔkius gali pasireikšti ịvairiais būdais. Dažniausiai, vykdydamos nacionalini planavimą, jos nusistato pajègumų rūšis, kurios yra būtinos esminèms gynybos funkcijoms užtikrinti. Šie pajègumai, nepaisant jokių aplinkybių, negali būti panaikinti arba būti daugianacionalinės iniciatyvos dalimi. Šis esminių pajëgumų sąrašas kiekvienoje šalyje bus kitoks. Dažniausiai jis apimtų mažo ir vidutinio nuotolio oro gynybą, oro stebëjimą, pakrančių apsaugą ir teritorinès gynybos vienetus, vadovavimo ir valdymo struktūrą. Kitos šalys, kaip Izraelis gali nuspręsti, kad mažo ir vidutinio nuotolio priešraketinè gynyba yra esminis pajègumas, o Prancūzijai branduolinis ginklas yra neatimama gynybos ir atgrasymo dalis.

Kaip išskirtinis atvejis galètų būti pateiktas teroristų užgrobto lèktuvo (Renegade aircraft) persekiojimas ir netgi numušimas, jeigu tas lèktuvas pradeda kelti pavojų ne tik jame esančių, bet ir kitų žmonių gyvybei. Kadangi lekktuvo su keleiviais numušimas yra ypač jautrus atvejis, dauguma valstybių nemato šioje srityje jokių galimybių išmaniosios gynybos iniciatyvoms. Kaip Struwe'́as, Rasmussenas ir Larsonas pabrěže, kad „90-ųjų viduryje Nyderlandai ir Belgija sukūrẻ bendrą oro erdvès stebejjimo stebejjimą ir kiekviena paeiliui prisièmé atsakomybę už atsaką ì incidentus ore. Šitas susitarimas buvo anuliuotas po rugsėjo $11 \mathrm{~d}$. atakų JAV, nes Nyderlandai pasitraukè iš šio susitarimo. "15 Šiuo atveju bendradarbiavimas pasiekè nacionalinio suvereniteto nustatytas ribas.

Kiekviena valstybė visada gali nusibrežti ribas, kurių negali peržengti jokios specializacijos, prioritetizavimo projektai ar daugianacionalinès inicia- 
tyvos. Mažos valstybės visada išlaikys tam tikrus esminius karinius pajėgumus, be kurių neįsivaizduojamas jų suverenumo gynimas ir nacionalinių užduočių vykdymas.

Nepaisant tam tikrų apribojimų, šios valstybès gali mielai dalyvauti kituose išmaniosios gynybos projektuose, kurie nesikerta su jų suvereniteto išlaikymo norais. Priešraketinès gynybos, kuro papildymo ore, strateginio pervežimo, integruoto žvalgybos, stebèjimo, taikinių nustatymo ir išžvalgymo (angl. ISTAR - Intelligence, Surveillance, Target Acquisition, and Reconnaisan$c e)$ ir kitos išmaniosios gynybos iniciatyvos yra stipriai remiamos mažujų valstybių. Jos mielai jungiasi prie panašaus pobūdžio projektų. Pavyzdžiui, NATO Antžeminio stebejjimo sistemos ${ }^{16}$ (angl. AGS - Alliance Ground Surveillance) ar Strateginio pervežimo iniciatyvos ${ }^{17}$ (angl. Strategic Airlift iniative) dauguma narių yra mažos šalys.

Antra, valstybės turinčios ịsipareigojimų kitose pasaulio dalyse, gali siekti išlaikyti didesnę autonominių veikimų laisvę. Tai ypač būdinga didesnèms valstybėms tokioms, kaip Prancūzija ir Jungtinè Karalystė. Šios šalys turi interesų visame pasaulyje, todèl jų galimybès dalyvauti išmaniosios gynybos projektuose yra mažesnis nei kitų. Pavyzdžiui, nei viena iš šitų šalių tiesiogiai nedalyvauja AGS ar AWACS projektuose, tačiau sukūré savarankiškas sistemas, kurias pateikia NATO ad hoc principu. Tačiau reikia pažymėti, kad tokio statuso išlaikymas darosi vis sunkesnis, o mažèjantys gynybos biudžetai verčia ieškoti alternatyvių sprendimų. Pavyzdžiui, Jungtinės Karalystės gynybos doktrina gana atvirai sako, kad „aljansai ir partnerystės yra ypatingai svarbūs šalies gynybai ir saugumui, reikia pripažinti, kad Didžioji Britanija retai gali ir privalo veikti viena. ${ }^{\text {"18 }}$ Panašias nuostatas galima rasti ir Prancūzijos gynybos Baltojoje knygoje.

Vis dèlto, nepaisant augančio spaudimo, didžiosios valstybės privalo vykdyti savarankiškas karines operacijas be tiesioginès sąjungininkių paramos (Jungtinès Karalystės konfliktas su Argentina yra puikus tokio įsipareigojimo pavyzdys). Tokių šalių pajègos yra pasiruošusios veikti savarankiškai, dažnai tokia nepriklausomybė garantuojama išlaikant ir nepriklausomą karinę pramonę. Prancūzijos Baltojoje knygoje rašoma: „Prancūzija turi išlaikyti technologijas ir pajėgumą kurti, gaminti ir išlaikyti tą karinę ịrangą, kuri yra esminè suverenumo prerogatyva ir kurios negalima jokiais būdais

\footnotetext{
${ }^{16}$ NATO Antžeminio stebėjimo sistemos projekto narès yra Bulgarija, Čekija, Estija, Italija, JAV, Latvija, Lietuva, Liuksemburgas, Norvegija, Rumunija, Slovakija, Slovenija,Vokietija.

${ }^{17}$ Strateginio pervežimo iniciatyvos narès yra Bulgarija, Estija, JAV, Lenkija, Lietuva, Norvegija, Nyderlandai, Rumunija, Slovenija, Vengrija ir dvi NATO partnerès - Suomija ir Švedija.

${ }^{18}$ British Defence Doctrine, KDP 0-01, 2011, Paragrafas 108.
} 
dalintis ir kurti su kitais. ${ }^{\text {"19 }}$ Nieko panašaus negalima rasti mažųjų valstybių dokumentuose.

Apibendrinant galima pasakyti, kad visos valstybès, netgi mažosios, turi pilną teisę sudaryti esminių karinių pajègumų sąrašą. Tokie pajẻgumai visada būtų kontroliuojami nacionalinių vyriausybių, o jų dalyvavimas išmaniosios gynybos iniciatyvose būtų išimtinis atvejis. Šis sąrašas galètų apimti esminius valdymo ir vadovavimo elementus, branduolinès ir kibernetinès gynybos pajègumus, specialiąsias pajègas ir t. t. Netgi prieštankinė ar priešlèktuvinè amunicija galètų būti išimtinai nacionalinis reikalas. Bendradarbiavimas šiose srityje būtų ribotas ir apsiribotų tik mokymu ar paruošimu. Sudarius tokị sąrašą gynybos planuotojai iš anksto žinotų apribojimus, kuriose srityse išmaniosios gynybos taisyklès nèra taikomos.

\subsection{Specializacija ir nišiniai pajègumai}

Išmaniojoje gynyboje specializacija reiškia valstybès pasirinkimą kitų sričių sąskaita. Dèl resursų skyrimo iš anksto pasirinktai sričiai, ji pasiekia didesnị už kitas valstybes kompetencijos lygị. ${ }^{20}$ Specializacija galima tiek plačiame pajègumų spektre, tiek plètojant kurị nors vieną siaurą pajėgumą.

Grimesas and Rolfe'as taip aprašè sprendimų prièmimo logiką dèl specializacijos ir nišinių pajègumų plètros: mažos valstybės yra priklausomos nuo didelių valstybių pajegumų. Kadangi didžiosios šalys turi visą pajègų spektrą, mažosios valstybès seka savo partnerių elgesị, nagrinejja jų silpnąsias ir stipriąsias puses. Šiuo atveju mažoji valstybė ypač atidžiai žiūrès ir stengsis koncentruoti savo resursus $\mathfrak{i}$ tas sritis, kur didžioji valstybẻ turi trūkumų ar kurioms ji teikia didžiausią prioritetą. Toks jų tarpusavio supratimas leidžia abiem pusėms efektyviai panaudoti resursus, bet kaip Heniusas pastebi, „tiesioginé specializacijos pasekmé yra tai, kad nemažai valstybių atsisako investicijų i kai kuriuos svarbius, bet brangius pajègumus, kurie susikoncentruoja tik kelių didžiųjų valstybių rankose". ${ }^{21}$ NATO yra akivaizdus tokio nevienodo pasiskirstymo pavyzdys, kur nemažai sričių (priešraketinės gynybos, degalų papildymo ore, integruoto žvalgybos, stebejjimo, taikinių nustatymo ir išžvalgymo) viena valstybè, t. y. JAV, turi daugiau nei 50 procentų bendro NATO potencialo.

\footnotetext{
${ }^{19}$ The French White Paper on defence and national security, 2008, p. 254.

${ }^{20}$ M.Flournoy, J.Smith, op.cit., p. 34.

${ }^{21}$ J.Henius, op.cit., p. 29.
} 
Tiesa, toks scenarijus susiklosto ne visada. Pasitikejjimo trūkumas, skirtingas grèsmių supratimas ir kiti veiksniai skatina mažas valstybes išlaikyti kuo platesni pajègumų spektrą. Tai pavojinga strategija. Jeigu maža valstybẻ nesugebės nusistatyti prioritetų ir sukoncentruoti resursų $i$ keletą svarbiausių sričių, vieną dieną ji atsibus, P. Pugh žodžiais, „su laivynu iš vieno laivo ir oro pajègomis

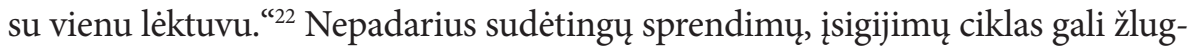
ti ir kaip ciniškai pastebèjo Grimesas ir Roelfe'as, kiekvienais metais galèsime džiaugtis „praeitais metais laivynas įsigijo vieną naują laivą, šiais metais oro pajègos nusipirks vieną lèktuvą, o kitais - sausumos pajegos vieną tanką!‘23.

Mažos valstybès paprastai specializacijos procesą pradeda nuo vadinamos „neigiamosios specializacijos“, t. y. jos neplètoja pajègumų, kurie nèra būtini nacionalinėms gynybos reikmėms. Lèktuvnešių grupès, ekspedicinẻ logistika, strateginio pervežimo orlaiviai, degalų papildymo ore ir kiti pajègumai dažniausiai nèra pirmo karinio būtinumo sąraše. Todèl tik penkios NATO narès (Prancūzija, Italija, Ispanija, Jungtinė Karalystė ir JAV) turi lèktuvnešius, tik keletas valstybių turi ilgo nuotolio bombonešius, vidutinio ir ilgo nuotolio priešraketinès gynybos sistemas, branduolinius povandeninius laivus ir t. t.

Antrasis žingsnis būtų prioritetizavimas. Mažos NATO valstybės jau irodè, kad kai reikia taupyti resursus, jos gali priimti sudètingus sprendimus ir nukreipti kariuomenès plètrą Aljansui reikalinga kryptimi:

- Danija nusprendè, kad neplanuoja dalyvauti konflikte, kuriame būtinas Danijos povandeninių laivų panaudojimas, ji pasitikès Nyderlandų ir Jungtinès Karalystès kontribucija ${ }^{24}$.

- Nyderlandų vyriausybė nusprendè, kad nebeinvestuos i jūrinès žvalgybos (angl. manned aerial maritime reconnaissance) pajègumus, resursai bus nukreipti ị kitas sritis, kur Nyderlandai turi didelę patirtị, pavyzdžiui, ryšiai ir jūriniai jutikliai. ${ }^{25}$

- Norvegija per keletą metų sumažino bazių infrastruktūrą, personalą ir savanorių pajègas, nutarusi resursus verčiau skirti perdislokavimo jūra, išminavimo, kalnų žvalgybos ir specialiųjų operacijų pajègų plètrai. ${ }^{26}$

Kai kuriose srityse negatyvi specializacija yra ne tik finansinių sprendimų, bet ir visų sajungininkų sutarto sprendimo pasekmė, kai Aljanso šalys sutaria užti-

\footnotetext{
${ }^{22}$ A.Grimes, J.Roelfe, op.cit., p. 279

${ }^{23}$ A.Grimes, J.Roelfe, op.cit., p. 279.

${ }^{24}$ I. Daalder, op.cit.

${ }^{25}$ M.Flournoy, J.Smith, op.cit., p. 75

${ }^{26}$ M.Flournoy, J.Smith, op.cit., p. 27.
} 
krinti mažosioms šalims tam tikras svarbias funkcijas. Geriausias tokio sprendimo pavyzdys yra NATO oro policijos misija Baltijos šalyse, kai NATO narès nusprendė saugoti Baltijos šalių oro erdvę, o Baltijos šalys turimus resursus geriau panaudoti bendroms Aljanso reikmèms. Reiktų paminèti, kad panašiu susitarimų pagrindu Belgija saugo Liuksemburgo, o Italija - Slovenijos oro erdvę.

Mažoms valstybès geriausias atsakymas ị specializacijos keliamus iššūkius yra balanso paieška. Iš vienos pusès jos turi aiškiai nusistatyti, kuriose srityse jos nori išlaikyti esminius karinius pajègumus, iš kitos - identifikuoti sritis, kurioms jos turi skirti ypatingą dèmesį, kartais ir kitų pajègumų sąskaita. Toks subalansuotas požiūris, nors ir nebūtų pats efektyviausias finansiškai, tačiau turètų bent minimaliai patenkinti tiek nacionalinius, tiek NATO reikalavimus.

\subsection{Regioninis požiūris ị išmaniają gynybą}

Daugianacionalinės išmaniosios gynybos iniciatyvos dažniausiai praktiškai igyvendinamos regioninio bendradarbiavimo ir iniciatyvų pagrindu. Siekiant išmaniosios gynybos iniciatyvoms suteikti realų pagrindą Flournoy ir Smith rekomendavo, kad „turi būti suburiamos šalių grupès, kurios turi santykini pranašumą ir yra nusiteikusios imtis iniciatyvos, kad pajegumų trūkumas vienoje ar kitoje srityje būtų panaikintas“. Flournoy and Smith pabrěžia, kad yra keletas sąlygų tokių valstybių grupių susiformavimui: gerai parengti operaciniai pajègumai ir atitinkama patirtis; nacionalinis ambicijų lygis; politinè lyderystė; istoriniai ir politiniai ryšiai; išplètota karinè pramonè ir ekspertize..$^{27}$ Politiniai ir kariniai veiksniai yra vienodai svarbūs.

Geografine padètis yra kitas svarbus veiksnys, lemiantis partnerių pasirinkimą ir išmaniosios gynybos iniciatyvų igyvendinimą. Svarbiausias kriterijus čia kaina - daug pigiau kainuotų pratybų metu perdislokuoti mechanizuotą batalioną iš Belgijos ị Nyderlandus negu i Graikiją. Panaši logika galioja daugumai jūrų ir oro pajègumų. Aišku, kai kitos alternatyvos neegzistuoja, valstybès yra pasirengusios mokèti didžiulę kainą už karinių vienetų perdislokavimą (pavyzdžiui, siunčiant naikintuvus pratyboms iš Europos ị JAV ar Kanados poligonus), tačiau finansinès krizès metais tai daryti darosi vis sunkiau.

Regioninès grupès susiformavo kaip atsakas $\mathfrak{i}$ šiuos geografinius apribojimus, nors bendra istorija, kalba ir kitos aplinkybès taip pat daro šiam bendradarbiavimui didžiulę ịtaką. Baltijos, Šiaurès, Šiaurès-Baltijos, Šiaurès Europos, Centrinès Europos, Pietryčių Europos, Adrijos jūros, Juodosios

${ }^{27}$ M.Flournoy, J.Smith, op.cit., p. 14 
jūros, Vyšegrado ir kiti formatai buvo sukurti siekiant skatinti regionini bendradarbiavimą ir integraciją. Kai kurie iš jų yra politinio bendradarbiavimo forumai, tačiau kituose (Baltijos, Šiaurès, Vyšegrado) gimsta praktinès išmaniosios gynybos iniciatyvos. Ne mažiau svarbus yra ir dvišalis bendradarbiavimas, kurio tikslai taip pat sutampa su išmaniosios gynybos idejomis (pavyzdžiui, Jungtinès Karalystès ir Prancūzijos bendros pastangos branduolinių ginklų srityje, Nyderlandų ir Jungtinès Karalystės jūrų pèstininkų bendradarbiavimas ir t. t.).

Mažosioms valstybèms regioninis bendradarbiavimas yra vienas pagrindinių būdų igyvendinti išmaniosios gynybos idëjas. Reikia pastebèti, kad nepaisant pozityvios politinès retorikos, net ir tarp homogeniškų regionų šalių pasitaiko politinių, techninių ir teisinių skirtumų, kurie lemia sunkumus ịgyvendinant konkrečius projektus. Tokie projektai dažnai velluoja, brangsta, tai dažnai verčia valstybes rinktis nacionalinius sprendimus, o ne leisti daugybę laiko bandant suderinti savo poreikius su partneriais.

\section{lšvados}

Mažosios valstybės teigiamai prièmè išmaniosios gynybos idèjas. Daugianacionalinis bendradarbiavimas leidžia joms sukurti pajègumus, kurių jos negalètų sukurti savarankiškai. Prioritetizavimas leidžia atsisakyti nebūtinų funkcijų ir panaudoti turimus išteklius pačioms svarbiausios sritims. Specializacija leidžia joms sutelkti resursus ị tas sritis, kur jos turi patirties ir pranašumo prieš kitus sąjungininkus. Šios kryptys negali būti automatiškai pritaikytos visoms šalims ar pajègumų kategorijoms. Valstybės požiūris ị išmaniosios gynybos teikiamus pranašumus išliks skirtingos.

Šis straipsnis parodè, kad keletas svarbių veiksnių trukdo arba atvirkščiai skatina valstybes pasirinkti ekonomiškus ir karine prasme efektyvius sprendimus. Stiprios kolektyvinès gynybos garantijos, solidarumas ir pasitikèjimas, finansinis spaudimas, didelis operacinis tempas skatina valstybes ieškoti inovatyvių ir išmanių sprendimų. Iš kitos pusès - politinis nepasitikejjimas, istoriniai nesutarimai, jautrumas suvereniteto klausimams - neigiamai veikia išmaniosios gynybos idejjų sklaidą.

Valstybių atsakas yra tiesiogiai susijęs su aukščiau paminètais veiksniais. Politinio nepasitikejjimo ar antipatijos atveju mažai tikètina, kad kelios valstybès sugalvotų ịkurti bendrus karinius vienetus. Iš kitos pusès, tik visapusiška pasitikejjimas gali lemti didelị integracijos laipsnị ir idealiu atveju gali inicijuoti net bendrų vadaviečių kūrimą. 
Šiame straipsnyje buvo parodyta, kad užnugario paramos, logistikos ir mokymo institucijos yra tinkamiausi išmaniosios gynybos projektams. Koviniai ir kovinès paramos ir administraciniai vienetai dèl politinių, nacionalinio suvereniteto ir kitų klausimų yra sunkiausi. Išmaniosios gynybos projektus lengviau igyvendinti, kai jie nesusiję su šalies esminiais kariniais pajègumais. Regioninis požiūris yra vienas iš galimų išmaniosios gynybos stiprinimo krypčių, tačiau jis turi ir silpnųjų pusių.

2013 m. kovas 